\title{
The role of international framework agreements in transnational labour regulation
}

\author{
Authors: \\ Helena du Preez ${ }^{1}$ \\ Paul Smit ${ }^{2}$ \\ Affiliations: \\ ${ }^{1}$ Department of Human \\ Resource Management, \\ University of Pretoria \\ ${ }^{2}$ Department of Human \\ Resource Management, \\ University of Pretoria \\ Corresponding author: \\ Dr P Smit \\ Paul.smit@up.ac.za \\ Dates: \\ Received: 30 October 2017 \\ Accepted: 10 November \\ 2017 \\ Published: 12 December \\ 2017 \\ How to cite this article: \\ Du Preez, H \& Smit, P. \\ 2017. The role of \\ international framework \\ agreements in transnational \\ labour regulation. South \\ African Journal of Labour \\ Relations, 41:64-74. \\ Copyright: \\ (c) 2017. South African Journal
} of Labour Relations

\begin{abstract}
The regulation of labour in the workplace is never an easy task but it is even more complex and challenging if it has to take place across national borders in a globalised world. Globalisation and a transnational labour environment impact on the ability of the employer to regulate or manage a labour force that is based in different countries. The migration of workers across national borders, the existence of multinational companies and the demands of transnational labour relations present management with many challenges. This article is premised on the conviction that corporate social responsibility codes and other codes of conduct, due to their voluntary nature, are not enough to effectively manage and regulate labour in a transnational environment. The authors suggest that international framework agreements are a far more effective management tool for transnational labour regulation.
\end{abstract}

Keywords: migration, transnational, labour relations, globalisation, corporate social responsibility, international framework agreements, labour regulation

\section{Introduction}

Economic globalisation exposes workers, along with their employment prospects and remuneration, to the changing environment of the global economy and international competition, while allowing them to be more mobile geographically. Transnational labour organisations have a tendency to regard globalisation as intimidating and a threat rather than a challenge. The belief that employees will organise across national boundaries in response to globalisation has not emerged very clearly in industrial relations theories (Greer \& Hauptmeier 2008). Taylor (1999) suggests that the question we should ask is: "Can we create the international policies and institutions to manage the process of globalisation in the service of the needs and aspirations of people?"

Since the year 2000, we have seen a clear acknowledgment from the transnational trade union movement that globalisation must be viewed as a new paradigm that demands new strategies, tactics and organisational modalities. Without a doubt globalisation has signalled the end of the labour movement's doing business in a "normal manner" and generated an entire range of ground-breaking responses as well as a gradually increasing flow of critical analysis (Munck 2010a).

Globalisation affords trade unions the opportunity to help manage change across national frontiers by ensuring that their transnational agenda of core standards of worker rights does not get lost in the midst of other pressures (Taylor 1999). According to Wills (1998), there are those in the trade union movement who argue that political and fiscal situations are ready for a rejuvenation of labour transnationalism since the attrition of national boundaries allows employees to make connections transversely.

Globalisation has undoubtedly generated a "potentially stronger workers' movement than ever existed before" (Munck 2010b:229). Taylor (1999:14) argues that "as national boundaries become blurred, rules established at national level, often after years of social struggle, are becoming as irrelevant as they are ineffective". One such rule is the global right of freedom of association set by the ILO, which has been critical for all employees. Munck (2010a) mentions that a national labour system has been rendered outdated by globalisation, with the emphasis 
on "national" as trade unions are presently transforming on a local, national, regional and transnational level.

\section{Migration}

Migration, regarded in this article as the free movement of labour across national borders, has many implications for the economy and for unions and other labour structures. Munck (2010a) is of the opinion that we are moving from a national to a transnational domain but that labour migration poses some challenges. However, according to Greer, Ciupijus and Lillie (2013), not all migrants are rooted in transnational labour markets so therefore there is no need for a transnational response. The transnational corporations (TNCs) were the primary movers of mobility in the early years, but since then finance, people and ideas have joined the world of flows, but none of these, and decidedly not labour, is what Munck calls "footloose and fancy free" (Munck 2010a).

According to Rodriguez and Mearns (2012), the last ten years have seen a major increase in transnational migration and the mobility of workers. They describe modern life as an "era of mobilities" which has had important implications for the demand and supply of labour. They argue that this has been attributed to globalisation and has been responsible for the renewed interest in the study of migration. Globalisation has had a persistent impact by articulating and perpetuating organised processes of closure, entrapment and repression, which are triggered by migration and augmented by the dynamics of employment relations (Rodriguez \& Mearns 2012a).

Migration is the key element in destabilising labour in the era of globalisation (Munck 2010a). According to Pyle (2006), transnational labour migration differs from the "international movement of goods, services or capital" and there are more limitations on the flow of individuals transnationally than on "goods, services, or capital". However, Munck (2010b:223) refers to the comment of Milton Friedman (a neo-liberal economist) on migration, namely "About migration, the least said the better". This is reasonable as there does not appear to be any valid reason why capital, investment and ideas can flow freely across national borders where labour cannot (Munck 2010a).

Munck (2010a) defines migration as the effortless movement of people. Munck (2010a) states that mobility is the keyword, motif and central characteristic in the era of globalisation. According to Rodriguez and Mearns (2012), migration and mobility are essential to the changing nature of the trade in goods, capital and labour across national borders and this process is assisted by globalisation. These dynamics have influenced the way labour relations are controlled, expressed and experienced in local and global workplaces, which appear to show the multidimensional impact of globalisation on labour relations. Global complexity is the most important feature of development and globalisation creates a new ground for global labour problems (Munck 2010a).

According to Munck (2010a), migration can be seen as both a threat to and an opportunity for labour and unions. Sufficient governance of transnational union networks helps to overcome the organisational struggles generated by globalisation and strengthens labour's general position in global governance (Helfen \& Fichter 2011). Rodriguez and Mearns (2012:585) emphasise the readiness of migrant workers to join trade unions in the countries in which they are employed and the "fundamental role unions play in supporting migrant workers and building bridges between them and the indigenous [people]". However, as cited by Rodriguez and Mearns, "internal politics of trade unions play a role in the perceived openness of unions to migrant worker membership" (Rodriguez \& Mearns 2012:586).

According to Deacon, Lombaerde, Macovei and Schröder (2011), the European Union (EU) is undoubtedly the best-known and most efficient example of the structure of "free movement of people" and facilitation of labour migration among the regional integration processes worldwide; however, the idea of facilitating labour migration is not restricted to the EU but has evolved in other parts of the world as well. Horvath (2012) mentions that since the right to re-enter a home country is no longer an issue, some migrant workers now choose to work in one country while remaining a citizen of another.

But why migrate to another country? According to Pyle (2006), transnational employees obtain jobs in other countries that normally pay more than they could earn at home. Rodriguez and Mearns (2012:585) agree; however, they state that although it is believed that transnational migrants are headed for a better place seeking improvement, the degree of these improvements must be reconsidered because although the level of pay is better than in their home country, employment generally "remains precarious for the standards of the host country".

Rodriguez and Mearns (2012) also mention that several legal and illegal migrants are working under "precarious" working conditions that are not easy to manage or regulate, and some migrants even believe they are not protected against unfair labour practices. According to Munck (2010b), precarious work is "a more recent term denoting the uncertain, difficult and unstable forms of labour to which immigrants are subjected". If we endorse the belief that those workers are migrating towards a "better place", why are employers going along with this? Employers use migration to challenge collective bargaining and employment regulation and particularly use subcontracting and "posting" to protect 
themselves from legal accountability while separating migrants from the monetary and social norms of the host population, thereby providing them with a particular, precarious status (Lillie \& Greer 2007)

According to Munck (2010b), for most of the world's workers national borders are like a "prison with open gates" in the so-called era of globalisation. There is no obvious way to bring the interests of local and migrant workers into line so the globalisation of commonality remains an academic and practical challenge for labour relations. Faced with globalisation, employers and organisations do not automatically seek to deregulate labour relations and condense union power, but instead they attempt to reinforce their national basis of competitiveness (Lillie \& Greer 2007).

Liu (2004:501) argues that globalisation does not guide us to a "borderless world" where money, information and other resources travel liberally around the globe, since some of these transfers are costly and complex. On the other hand, Rodriguez and Mearns (2012) state that the metaphor of the "borderless world" can imply that workers benefit from the opportunities available in other countries and all that workers have to do is migrate towards those opportunities. However, as cited by Rodriquez and Mearns, labour market stringency and the realities of disparities, mobility constraints and deskilling are reported as fundamental to migrant workers' experiences. In this case, globalisation has undermined the status quo between capital and labour and in both situations, migration has been essential to reshaping labour relations.

According to Bieler (2005), there is a growing body of literature on the role transnational capital plays, but we need to start focusing on the potential function of labour as a transnational actor. The transnationalisation of labour markets in the production industry are an example of this and one that has gone particularly far (Lillie \& Greer 2007). However, according to Murray (2002), there is no body of labour law that is fully able to take account of transnational firms, but these authors do recognise numerous developing areas in which labour law is competent to some degree to rise above national boundaries and take account of the activities of transnational firms. See the section on transnational labour regulation.

According to Dickmann, Müller-Camen and Kelliher (2008), transnationals need to integrate various human resource principles and policies to create cohesion. In other words, as Gennard (2008) states, an important part of becoming a "transnational" company is to execute transnational human resource management (THRM). Nevertheless, Dickmann et al (2008) point out that organisations face a lot of challenges when they practise or implement THRM. Transnational firms are thought to be integrated and differentiated at the same time. Well-developed communication and management processes are necessary for that reason to identify where THRM standardisation is probable and where local awareness is necessary (Dickmann et al 2008).

Problems arise where decisions taken in one area of the globe have an effect on employment relations elsewhere in the world. As Lillie and Greer (2007:574) argue, "Transnational relationships of actors have become so intertwined that it is difficult to understand the strategies of actors within one country without reference to events and actors in other countries." Lillie and Lucio (2012) mention that transnational capital plays national environments off against each other but at the same time attempts to create a genuinely global business environment. Although decisions on employment matters are sometimes "local" in nature, they could also be transnational (Murray 2002).

According to De Jonge (2011), the occurrence of TNCs is not a new concept, but the constantly increasing levels of power and pressure of TNCs within the globalised world is extraordinary. The rapid growth of TNCs has been accompanied by increasing concern about their effects on employment structure, security and conditions in host countries (Marginsons 1992). As workers shift from one national setting to another, they draw on rules and resources from transnational contexts, where new configurations of interests and balances of power have emerged. This, however, is difficult for "nationally bounded institutional analysis to forecast and understand (Lillie \& Greer 2007). Dickmann et al (2008) also mention that management and academics oversimplify the process of becoming transnational since organisations have to manage difficult environments and actors who have their own security at heart and their own power bases.

When companies operate across borders, there is a need to link different parts of the company to different member states. This may entail changes in production or the adoption of new technology, with the result that changes in one part of the company could have major implications for the employment of people somewhere else in the company. As a result, companies may need to develop a transnational approach to employment matters (Marginsons 1992).

\section{Transnational labour relations}

The globalisation of markets and firms has transformed labour relations (Greer \& Hauptmeier 2008). According to Lillie and Lucio (2012), it is still not clear exactly what "labour transnationalism" means, who the people involved are and what sort of analytical frameworks might be applied in order to understand their activities. However, Greer and Hauptmeier (2008:77) define labour transnationalism as 
"the spatial extension of trade unionism through the intensification of co-operation between trade unionists across countries using transnational tools and structures".

According to Greer and Hauptmeier (2008), political entrepreneurs play a vital role in the development of labour transnationalism. In the article by Greer and Hauptmeier (2008) the term "political entrepreneur" refers to the discovery of transnational strategies by single unionists and their organisations. These so-called political entrepreneurs have the vision to look at transnational strategies and the leadership skills to prove their constituency. According to Greer, Ciupijus and Lillie (2013:7), the labour transnationalism literature treats union organizing as just one of many reasons why unions would work across national boundaries".

In the view of Helfen and Fichter (2011:4), "academic research is only beginning to deal with what we would define as an emerging arena of transnational labour relations". A new labour relations group has emerged at a European level whose main purpose is to place worker representatives in touch with each other (Wills 1998). According to Horvath (2012), the rise of the EU is a landmark for a development that has involved the globalisation of capital and trade flows and resulted in the establishment of a new transnational regulations system plus the reformation of general economies and welfare states. It is on this basis that different forms of transnational labour relations have emerged.

According to Helfen and Fichter (2011), we need to re-conceptualise the discussion on transnational labour relations. The call for more transnational labour relations requires the trade unions to reassert their main objectives in contemporary language that resonates in the flexible labour markets and workplaces (Taylor 1999). When we take the formative framework of transnational labour relations into account, the "arena concept offers a more viable starting point for investigating the interaction between GPNs and global union federations [GUFs] than notions of a global labour regime" (Helfen \& Fichter 2011:4).

There are obvious obstacles to the development of a realistic and permanent transnational labour relations system and transnational trade union federations must decide on strategies for confronting the countless challenges from increasing globalisation (Taylor 1999). According to Marginsons (1992), transnationals face many problems in managing scale, diversity and space, but these challenges can be resolved through a company's internal organisational structure. Where transnationals are geographically diversified and similar products or services are produced in various locations, the usual forms of labour relations conflict may arise (Marginsons 1992).

Munck (2010a), one of the more positive but nevertheless realistic researchers, states that labour must take advantage of the transnationalisation process and be able to organise on a local, national, regional and global scale. According to Taylor (1999), the development of transnational labour relations is of great importance, especially if organised labour is to have some hope of mobilising and enhancing its power through international agreements.

De Jonge (2011) notes that TNCs are beginning to realise the limits of the state duty to protect them and their employees, and acknowledge that they have an obligation to respect human rights and labour rights as these are not just an issue for governments. When discussing the role of TNCs it is important to realise that there is an ambiguous relationship between transnational labour relations systems, the unions and the state (Lillie \& Lucio 2012).

Seen from a political and economic point of view, the development of global production networks (GPNs) transnationalised the arena of transnational labour relations, introducing new conflicts of interest (Helfen \& Fichter 2011). GUFs are responsible for the idea of International Framework Agreements (IFAs), which have turned into a strategy to improve working conditions by building more trade unions in order to achieve a greater shared employee voice in transnational labour relations (Helfen \& Fichter 2011). GUFs acknowledged the important impact that IFAs have on TNCs by introducing a framework that moves across borders, recognising the norms, principles and procedures of transnational labour relations (Helfen \& Fichter 2011).

Organisational structures and strategies are important in explaining different patterns of labour relations within organisations (Greer \& Hauptmeier 2008). According to Marginsons (1992:538), there are strategies available to management to standardise their labour relations arrangements across different settings, which might guide management towards adopting a common approach to handling labour relations. Greer and Hauptmeier (2008) identify two types of transnational management strategies, namely the production and labour relations strategies, which are fundamental in shaping labour transnationalism.

When organisations are functioning across borders, in other words as transnational companies, management is more likely to develop a common approach to managing its workforce and thus seek a more transnational approach to handling labour relations (Greer \& Hauptmeier 2008). During acquisitions different management styles are absorbed, including different styles in managing labour relations. Mergers and acquisitions are frequent and involve the breaking down of traditions, which may be a difficult and complex process; therefore, adopting a transnational approach to labour relations 
might ease matters (Greer \& Hauptmeier 2008; Marginsons 1992). However, Marginsons (1992) points out that where businesses are operating in different locations and producing unrelated goods and services, the need for a universal management approach is not particularly high, and developing transnational policies relating to labour relations might even prove to have a negative effect on employees and thus on production.

In other words, management can follow a centralised or a decentralised approach when managing labour relations (Greer \& Hauptmeier 2008) but organisations will not have an interest in developing a transnational approach to labour relations management unless there is a strong link between the various activities performed or services rendered in the different countries (Marginsons 1992). Moving from a traditional or regional approach to a transnational approach in handling labour relations might depend on the organisational structure and management style, but it does not guarantee success (Marginsons 1992).

\section{The rise of corporate social responsibility (CSR)}

The concept of corporate social responsibility was introduced during the early twentieth century in the United States and was instigated by wealthy business people who believed that companies are more than simply profit-generating entities (Kolk, Van Tulder \& Welters 1999). This notion owes its origin to concerns regarding the inequality created by the growing size and power of companies. After this rise, the importance of CSR diminished during the Great Depression of the 1930s and in the 1950s following the Second World War (1939-1945) (Kolk, Van Tulder \& Welters 1999).

The current position is, as Thomas Gad, a famous marketing researcher, stated: "For most companies it can be said that they won't necessarily get more customers by being socially responsible, but they definitely risk losing customers by not being socially responsible" (Riisgaard 2005:714).

There is currently no universal agreement on how to develop indicators to evaluate the CSR of a company (Kolk, Van Tulder \& Welters 1999). The concept of CSR includes three levels of analysis (society, company and management) with three complementary principles: "at social or company level, the principle of legitimacy; at the organisational level, the principle of public responsibility; and at the individual level, the principle of managerial discretion" (Kolk, Van Tulder \& Welters 1999:150). Codes of conduct are applicable to all three levels.

\section{$5 \quad$ Labour and corporate social responsibility}

Although corporate companies are adopting CSR mainly for profitability and damage prevention, this new environment also enables companies to "identify overlapping interests between employers and workers and thereby cooperation through negotiated initiatives" (Riisgaard 2005:716). Furthermore, the fact that CSR provides "new possibilities for union cooperation across geographical and political boundaries" has given labour new influential tools in terms of openly questioning businesses in their outlet markets (Riisgaard 2005:716). This also facilitates the combining of bargaining power between NGOs, consumers and investors.

An important question asked by various labour relations experts and managements of TNCs, is whether corporate codes of conduct can actually play a role in "monitoring compliance with international labour standards and improving working conditions in global supply chains" (Locke, Kochan, Romis \& Qin 2007:21). On this matter Riisgaard (2005:716) states that workers can exploit this new CSR climate to ensure respect for basic workers' rights by 'forming alliances with NGOs and engaging in internationally negotiated agreements with employers in what could be called new forms of social contracts" (Riisgaard 2005:716). Whether the behaviour of TNCs can be regulated through codes of conduct has always been an ongoing debate (Kolk, Van Tulder \& Welters 1999).

The new social movements, associated with globalisation, are raising questions regarding workers' rights and employment conditions in the global economy. However, countless workers are aware of the need for self-organisation whereas many employers still have reservations about these concerns (Wills, 1998). The debate on voluntary self-regulation has been going on since the 1970s but the lack of "international consensus about the function, the wording and about potential sanctions against noncompliant firms" has weakened the original objective of making the codes binding (Kolk, Van Tulder \& Welters 1999).

Because of the voluntary nature of CSRs, they are not sufficient to ensure transnational labour regulation.

\section{International framework agreement overview}

International framework agreements are a rapidly developing phenomenon; they doubled in number from 11 at the beginning of 2001 to 22 by mid-2002 and increased to 30 in 2005 (Riisgaard 2005). At 
the time of writing at least 100 such agreements have been signed (Global Union 2009). IFAs were introduced to "overcome shortages in the national regulations of employment practices in cross-border production and supply networks" (Fichter, Sydow \& Volynets 2007:18). Through IFAs, GUFs strive for communal acceptance of globally accepted standards, normally addressing their representations to governments. IFAs can be seen as an instrument used for the regulation of employment relations in TNCs and their supply networks (Fichter, Sydow \& Volynets 2007; Telljohann et al 2009; Sobczak 2007). Hammer (2005) concurs and states that IFAs establish a vital and innovative tool for transnational labour relations, depending on the different features of international trade union activity such as codes of conduct. He nevertheless argues that IFAs are still "far from a mature industrial relations tool" (Hammer 2005:514).

IFAs aim to "secure core labour rights across multinational corporations' global supply chains" (Hammer 2005:11) and can be seen as a "new form of regulation at a transnational company level" (Telljohann et al 2009:507). The concept international framework agreement can be used as a broad term to refer to all agreements that extend across national boundaries (Telljohann et al 2009). Riisgaard (2005:709) describes IFAs as "agreements on minimum labour standards negotiated between GUFs and MNEs" whereas GUFs define IFAs (also called "global framework agreements") as agreements signed between senior management of a TNC and a GUF. Telljohann et al (2009) agree with that definition but add an additional criterion, namely, scope of application. Ultimately, IFAs "specify the minimum social standards which are to be applied throughout TNCs" (Fichter, Sydow \& Volynets 2007:9).

An increasing number of international unions are signing IFAs with TNCs to secure their promise to respect fundamental worker rights (Riisgaard, 2005). IFAs can result from "the activities of different trade union structures and may go part of the way towards establishing regular bargaining relations". Similarly, they can also constitute the "starting point for putting labour on the map by according it organising rights in the first place" (Hammer 2005:512).

Riisgaard (2005) points out that IFAs contain a minimum "freedom of association" and the "right to collective bargaining" and provide unions with official representation at company level. This representation at business level is one of the main elements that primarily distinguish IFAs from other voluntary initiatives. Another important distinguishing factor is that IFAs are negotiated between a transnational employer and the regional, national and international unions that represent the workers included and protected by the agreement (Riisgaard, 2005). Furthermore, IFAs offer unions a place in the monitoring and compliance process. IFAs allow workers to decide what is best for them.

The underlying principle of IFAs can therefore be seen as self-organisation and, although GUFs can encourage local attempts at organisation, the execution of an IFA relies on unions' and workers' decision to participate and perform their duties (Wills 1998). Riisgaard (2005) argues that when used optimally, the case of IFAs reveals new and favourable labour strategies for securing workers' rights within TNCs where unions and non-governmental organisations (NGOs) act as partners in safeguarding labour-negotiated agreements.

IFAs extend voluntary CSR commitments (such as codes of conduct) since they provide a contractual basis for TNCs and trade unions to outline standards of employment and describe procedures to ensure implementation (Weiss 2013). Nevertheless, they do not replace enforceable legal rulings. However, the descriptions of the rights, tasks and duties of the relevant parties can be an instrument for fighting global disorder and making sure core labour standards are implemented by TNCs (Fichter, Sydow \& Volynets 2007). There are currently no model agreements or legal framework for IFAs (Weiss 2013), but even if such models were to be developed by GUFs, no two IFAs are the same and development should take place accordingly (Sobczak 2007). However, when signatory parties plan to establish an IFA, they should first analyse some existing IFAs of other companies, which will assist in the development of their own agreement.

Figure 1

IFA's signed by respective countries 1987-2007

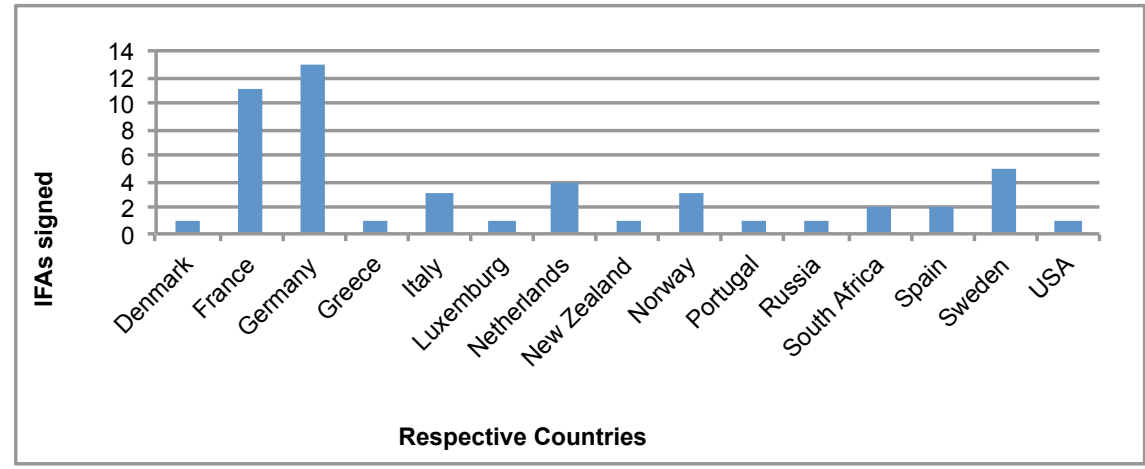


These agreements were negotiated between TNCs and international trade union federations in an attempt to define labour standards for their workers, their subsidiaries and in most cases, their subcontractors as well (Sobczak 2007). It is clear that for as yet unknown reasons very few IFAs have been signed in countries outside Europe seeing that unions from other countries have been reluctant to make use of this tool (Fichter, Sydow \& Volynets 2007). This can be harmful to the validity and acceptance of IFAs in those countries and might call into question the strategic direction and relevance of the international trade union (ITU) movement.

During the last few years IFAs have emerged as a "new tool of regulation within transnational companies" (Telljohann et al 2009:507). According to Hammer (2005), the 1990s should be seen as a critical turning point in transnational labour strategy. As in a developing innovative global political economy, labour has progressively reinstated itself as a player in this framework and begun to outline new methods, approaches and bodies of transnational labour relations. Hammer (2005) points to some examples of how this has been achieved, such as the fact that labour has succeeded in taking some of the "CSR terrain" through its contribution in formulating codes of corporate conduct. Secondly, labour has also caused trade unions to launch several structures within TNCs, thereby establishing the foundation for continuous transnational union collaboration (Rüb 2002). Thirdly, there has been the emergence of IFAs, a development related to both these previous advances. IFAs augment existing labour relations arrangements and "bind fragmented structures and practices at the level of international organisations and TNCs into an interesting governance structure" (Hammer 2005:514).

One mechanism for securing workers' rights that appears to overcome some of the challenges of codes of conduct is international framework agreements (Riisgaard 2005). Where GUFs have enough power and the necessary networks of communication to senior management in TNCs, they can negotiate agreements that extend codes of conduct. As Wills (1998) states: "rather than statements of good intent, International Framework Agreements allow the unions a role in establishing the terms of good conduct and in monitoring developments on the ground". Because IFAs recognise GUFs and other union bodies, they are protected by unionists as a symbol of practical social dialogue and relationships on an international level (Weiss 2013). This is a condition required for developing a legal framework for labour standards and provides an incentive to pursue the goal of transnational labour relations (Fichter, Sydow \& Volynets 2007; Telljohann et al 2009).

According to the global unions federations, the minimum requirements for an IFA are contained in six key points, in other words, six criteria have been identified for defining an agreement as an IFA, namely: the global reach of the agreement, references to the ILO Conventions, extension to suppliers, a GUF as a signatory, trade union involvement in the implementation, and the right to bring complaints (Hammer 2005; Nilsson 2002; Fichter, Sydow \& Volynets 2007). Fichter, Sydow and Volynets (2007:10-11) used previous research together with the current 53 identified IFAs in 2007 to develop the following ten categories as useful and relevant when defining an IFA:

1 ILO core labour standards

2 Inclusion of other ILO standards

3 Reference to other international agreements

4 Range of topics

5 Notification and publication of the IFA

6 Regulation of union involvement

7 Duration of the agreement

8 Monitoring

9 Dispute resolution

10 Compliance by suppliers and subcontractors

As a result of the above, IFAs create a platform for transnational labour relations by defining GUFs as valid bargaining partners (Hammer 2005; Weiss 2013). It is clear that they cover more than traditional codes of conduct seeing that they are not simply independent declarations, but contain obligations, even though they are not legally enforceable. In addition, they deal with government failure by "setting global minimum standards and by getting TNCs to accept responsibility for their labour rights situation" (Hammer 2005:518).

Labour is one of the leading players in the implementation process, together with regular monitoring. IFAs typically obligate TNCs to comply with the core labour standards stipulated in the 1998 ILO Declaration on Fundamental Principles and Rights at Work which takes the form of ILO Conventions 29, 87, 98, 100, 105, 111, 138 and 182 (Weiss 2013). The International Labour Conference regards these principles as essential and therefore assumes that all ILO members are bound by them. This converts global unions into bargaining parties to TNCs and makes them part of a voluntary enforcement mechanism (Hammer 2005). 


\section{The main features of IFAs}

Hammer (2005:514) summarised some of the main functions of IFAs in arguing that these agreements-

i form GUFs, World Work Councils, EWCs and other regional and national trade union structures, as labour relations actors at an international level;

ii allow company-level agreements to cover more suppliers upwards along the global supply chain; and

iii bind company-level agreements on core labour rights to traditional social dialogue, referring to multifaceted tools such as "the ILO Tripartite Declaration, the principles of the UN Global Compact and the revised OECD Guidelines" on TNCs.

Many IFAs do not increase the rights of workers who signed a contract of employment seeing that they are already protected by labour law (Sobczak 2007). Nevertheless, they still add value for the "workers in subsidiaries and subcontracting companies" as the signature of such an agreement proves that the company accepts responsibility for defending their social rights (Sobczak 2007:470). It can therefore be said that the scope of application of some IFAs moves beyond the TNC and includes subcontractors (Telljohann et al 2009; Fichter, Sydow \& Volynets 2007). Wills (1998), on the other hand mentions in his article on bargaining space in the global economy that IFAs and their associated activities will only benefit workers employed directly by TNCs unless the agreement clearly states that it is extended to subcontractors. IFAs usually state whether their standards apply to the entire group or only to specific parties. For example, the BMW agreement signed in 2005 states: "The goals and principles of implementation set out in this joint declaration apply for the BMW Group worldwide" (Sobczak 2007:470).

Stakeholders should use IFAs optimistically and not worry about the traditional sense of the definition, even though there is no single specific way to negotiate such agreements, in view of the significant arguments about the global character of these agreements. Trade union collaboration through the global supply chain can ultimately only be effective if it is global. In this regard Hammer (2005) points out that GUFs should be given a principal role in the process and "Southern" unions should be integrated as an approach to improving representation and linking different positions (North and South) within the labour movement. If developments from national or regional platforms can be projected onto a global level, it is important to distinguish what process agreement negotiations should follow as well as who the representative structures will be.

In contrast to codes of conduct, most IFAs include detailed requirements on their implementation procedures; nevertheless they both view implementation as an important factor in TNCs (Sobczak 2007). According to Fichter, Sydow and Volynets (2007:12), the following elements all contribute to ensuring effective implementation of IFAs: "different institutional and legal frameworks, business cultures and attitudes, intra-organisational structures, the role of local management, subcontractors, and suppliers as well as issues of union involvement and resources". Most IFAs include some form of enforcement mechanisms but these mechanisms are restricted to grievance procedures which are controlled by joint review bodies (Fichter, Sydow \& Volynets 2007). It is therefore possible to monitor such agreements.

When developing and implementing IFAs, trade unions play an important role and have the following four intertwined strategic objectives (Telljohann et al 2009; Rüb, 2002):

1 The establishment of minimum social standards in all the TNCs' operations worldwide, including their suppliers and subcontractors;

2 the development of a continuing dialogue with management at international and national/local level;

3 supporting trade unions with the organisation of campaigns in the respective TNCs and their suppliers; and

4 the improvement of international cooperation between trade unions through the establishment of worldwide trade union networks within TNCs.

\section{Concluding remarks}

As firms proclaim their support for ethical practice in construction and services, several GUFs have seized the opportunity to sign IFAs with transnational companies (Wills 1998). These international framework agreements ensure that the TNC commitments to respect workers' rights are honoured. The development of IFAs is related to two concomitant benefits. On the one hand, businesses plan to improve the reliability and validity of their activities and strategies in the field of CSR (Sobczak 2007). On the other, trade unions are familiar with the fact that such negotiated agreements may supplement the current national and international devices of social regulation that are still insufficient to address the challenges of globalisation (Sobczak 2007; Hammer 2005). 
As mentioned previously, IFAs constitute a complex transnational labour relations tool; however, they require involvement from "all stages from negotiation, implementation, monitoring through continuous representation, and at all levels of the labour movement" (Hammer 2005:511). IFAs are "a new instrument for industrial relations at the global level that instils recognition of social partnership across national borders and yields entirely new forms of social regulation at global level" (Telljohann et al 2009:521).

IFAs protect and advance workers' rights within TNCs (Riisgaard 2005). They also provide a platform which can be used to form coalitions with other social movements to 'fight for workers' rights in the global economy" (Wills 1998:267). As Riisgaard says (2005:730), when "seen in relation with the internationalisation of capital and the need for alternative labour strategies, IFAs represent a promising device". In a fieldwork study conducted by Riisgaard (2005) on these agreements, he argues that although IFAs have certain drawbacks, they hold promise as a way to protect and improve workers' rights within TNCs by combating competition between workers from different nations, and making space for union organisation, collective bargaining and social dialogue.

Endorsing and extending the right to organise by means of a union-assigned IFA provide a tool to "support local organisation and prevent the violation of workers' rights" (Wills 1998:695). In general, TNCs regard IFAs as "a tool for deepening dialogue with employees in order to ensure industrial peace, enhance the company's image, and legitimise their CSR policies through the incorporation of employment issues" (Fichter, Sydow \& Volynets 2007:20). International labour organisations (for example GUFs) view IFAs in terms of their acknowledgement by TNCs of the emergence of transnational labour relations. If this is not addressed, these differences, together with the lack of adequate implementation, may challenge the prospects of IFAs growing into widely accepted tools that regulate labour relations across national borders (Fichter, Sydow \& Volynets 2007).

In a study conducted by Telljohann et al (2009) the authors analysed four in-depth IFA cases and concluded that most European companies have developed labour relations on an international level; furthermore they demonstrated that IFAs can contribute to the internationalisation of labour relations. Through their scope of application, the rights they confer and the monitoring procedures they put in place, IFAs have the potential to contribute to more effective social regulation within transnational groups and global supply chains (Sobczak 2007).

\section{Conclusion}

From a political and economic point of view, the development of GPNs has transnationalised the arena of transnational labour relations, introducing new conflicts of interest. GUFs introduced the idea of IFAs, which turned into a strategy to improve working conditions by building more trade unions in order to achieve a greater shared employee voice in transnational labour relations (Helfen \& Fichter 2011).

From the GUFs' representative point of view, IFAs have been very effective so far in protecting fundamental trade union rights that are covered by conventions of the ILO, specifically with regard to conventions 87 and 98 (Global Unions 2009).

No standard model for IFAs exists; however, most agreements focus on the issues covered by the core conventions of the ILO, in particular, conventions 87 and 98 (Lillie \& Geer, 2007). Looking at the history, the need for IFAs can be traced back to globalisation. An important question to consider is how labour can be protected in the context of a globalised world. The answer seems to be that IFAs incorporate freedom of association as well as the right to collective bargaining and present unions with official representation at corporate level (Riisgaard 2005).

The aim of IFAs is to provide protection and ensure compliance with core labour rights across TNCs' global supply chains (Hammer 2005). The purpose of IFAs is to encourage global social dialogue between the "multinationals and the representatives of workers", in other words, between headquarters and the physical location of the company where it operates (Gennard 2008).

Although IFAs are not yet fully established, they represent a significant and ground-breaking tool in transnational labour relations based on different features of international trade union activity (Hammer 2005; Telljohann et al 2009). An increasing number of transnational unions are signing IFAs with TNCs, ensuring their "commitment to respect fundamental workers' rights" (Riisgaard 2005:707). IFAs constitute a multifaceted labour relations tool that requires extensive participation and contributions at all stages, from "negotiation, implementation, monitoring through to continuous representation, and at all levels of the labour movement" (Hammer 2005:527).

The minimum requirements of an IFA can be summarised in six focal points (Hammer, 2005:515), namely: it must be a global agreement; conventions must be referenced to the ILO; it has to require the TNC to influence suppliers; a global union federation should be a signatory; there has to be trade union involvement in the implementation; and there has to be a right to bring complaints.

IFAs generally specify that monitoring must be done by the representatives of the different parties involved, although in some instances it is conducted by an "existing representative structure" such as 
the European Work Councils (EWC) or World Company Work Councils (Bourque 2008).

By defining GUFs as lawful bargaining partners, IFAs create a platform for transnational labour relations (Hammer 2005). Perhaps one of the most significant innovations of IFAs is that they permit the existence of trade unions with a tight grasp on the global supply chain, and in that way, extend fundamental labour rights beyond national borders (Hammer 2005).

It can therefore be concluded that international framework agreements form part of a transnational labour relations system as they attempt to regulate labour in TNCs at the international level. Although both IFAs and codes of conduct are voluntary, IFAs embody a much more comprehensive implementation and monitoring system.

\section{List of references}

Bieler, A. 2005. European integration and the transnational restructuring of social relations: The emergence of labour as a regional actor? Journal of Common Market Studies, 43(3):461-484. Available at: DOI:10.1111/j.0021-9886.2005.00565.x.

Bourque, R. 2008. International framework agreements and the future of collective bargaining in multinational companies. Just Labour: A Canadian Journal of Work and Society, Vol 12, Spring 2008.

De Jonge, A. 2011. Transnational corporations and international law: Bringing TNCs out of the accountability vacuum. Critical Perspectives on International Business, 7(1):66-89.

Deacon, B, De Lombaerde, P, Macovei, MC \& Schröder, S. 2011. Globalisation and the emerging regional governance of labour rights. International Journal of Manpower, 32(3):334-365.

Dickmann, M, Müller-Camen, M \& Kelliher, C. 2008. Exploring standardisation and knowledge networking processes in transnational human resource management. Personnel Review, 38(1):5-25.

Fichter, M, Sydow, J \& Volynets, L. 2007. Organization and regulation of employment relations in transnational production and supply networks: Ensuring core labor standards through international framework agreements? Paper presented at the 21st EGOS Colloquium, Subtheme 16 "Slippery Dance Floors: The Changing Role and Responsibility of Business in the Global Society", Vienna, July $5-7,2007$.

Gennard, J. 2008. Negotiations at multinational company level? Employee Relations, 30(2):100-103.

Global Unions. 2009. Framework Agreements. Available at: http://www.global-unions.org/+-frameworkagreements-+.html (accessed 8 June 2015).

Greer, I \& Hauptmeier, M. 2008. Political entrepreneurs and co-managers: Labour transnationalism at four multinational auto companies. British Journal of Industrial Relations, 46:76-97. Available at: DOI: $10.1111 / \mathrm{j} .1467-8543.2007 .00667 . x$.

Greer, I, Ciupijus, Z \& Lillie, N. 2013. The European Migrant Workers Union and the barriers to transnational industrial citizenship. European Journal of Industrial Relations, 19(1):5-20.

Hammer, N. 2005. International framework agreements: Global industrial relations between rights and bargaining. Transfer: European Review of Labour and Research, 11(4):511-530.

Helfen, M \& Fichter, M. 2011. Global production networks and global union federations: Re-assembling transnational union networks by International Framework Agreements? Paper presented at the Global Labour University Conference, At Johannesburg, South Africa, January 2011.

Horvath, K. 2012. National numbers for transnational relations? Challenges of integrating quantitative methods into research on transnational labour market relations. Ethnic and Racial Studies, 35(10):1741-1757.

Kolk, A, Van Tulder, R \& Welters, C. 1999. International codes of conduct and corporate social responsibility: Can transnational corporations regulate themselves?. Transnational Corporations, 8(1):143-180.

Lillie, N \& Greer, I. 2007. Industrial Relations, migration, and neoliberal politics: The case of the European construction sector. Politics \& Society, 35(4):551-581.

Lillie, N \& Lucio, MM. 2012. Rollerball and the spirit of capitalism: Competitive dynamics within the global context, the challenge to labour transnationalism, and the emergence of ironic outcomes. Critical Perspectives on International Business, 8(1):74-92.

Liu, W. 2004. The cross-national transfer of HRM practices in MNCs: An integrative research model. International Journal of Manpower, 25(6):500-517. 
Locke, RM. 2003. The promise and perils of globalisation: The case of Nike. Management: Inventing and delivering its future:39, 40. Massachusetts Institute of Technology, Working Paper IPC -02-007. Industrial Performance Centre, Cambridge, MA.

Locke, R, Kochan, T, Romis, M \& Qin, F. 2007. Beyond corporate codes of conduct: Work organization and labour standards at Nike's suppliers. International Labour Review, 146(1-2):21-40.

Marginsons, P. 1992. European integration and transnational management: Union relations in the enterprise. British Journal of Industrial Relations, 30(4):529-545.

Munck, R. 2010a. Globalisation, migration and work: Issues and perspectives. TRAVAIL, Capital et Société, 43(1).

Munck, R. 2010b. Globalisation and the labour movement: Challenges and responses. Global Labour Journal, 1(2):1.

Murray, G. 2002. Introduction. Relations Industrielles/Industrial Relations, 57(1):5-7.

Nilsson, J. 2002. A tool for achieving workers' rights. Metal World, 4:22-27.

Pyle, J. 2006. Globalisation, transnational migration, and gendered care work: Introduction. Globalisations, 3(3):283-295. Available atL DOI:10.1080/14747730600869938.

Riisgaard, L. 2005. International framework agreements: A new model for securing workers' rights? Industrial Relations: A Journal of Economy and Society, 44(4):707-737.

Rodriguez, JK \& Mearns, L. 2012. Problematising the interplay between employment relations, migration and mobility. Employee Relations, 34(6):580-593.

Rüb, S. 2002. World works councils and other forms of global employee representation in transnational undertakings. Working Paper No 55, Düsseldorf: Hans Böckler Stiftung.

Sobczak, A. 2007. Legal dimensions of international framework agreements in the field of corporate social responsibility. Relations Industrielles/Industrial Relations:466-491.

Taylor, R. 1999. Trade unions and transnational industrial relations. Labour and Society Programme. International Institute of Labour Studies, Discussion Paper DP/99/1999, Geneva, Switzerland

Telljohann, V, Da Costa, I, Müller, T, Rehfeldt, U \& Zimmer, R. 2009. European and international framework agreements: New tools of transnational industrial relations. Transfer: European Review of Labour and Research, 15(3-4):505-525.

Weiss, M. 2013. International labour standards: A complex public-private policy mix. The International Journal of Comparative Labour Law and Industrial Relations, 29(1):7-20.

Wills, J. 1998. Taking on the CosmoCorps? Experiments in transnational labor organization. Economic Geography, 74(2):111-130. 